\title{
CRIMSONpublishers
}

\author{
http://www.crimsonpublishers.com
}

Opinion

ISSN 2637-7802

\section{Rasa Panka (Fundamentals of Dravya Guna Shastra Vijnana)}

\author{
Venkata N Joshi* \\ Croydon Ayurveda Centre, Middlesex University, London \\ *Corresponding author: Venkata N Joshi MD, Ayurveda, Croydon Ayurveda Centre, Middlesex University, London
}

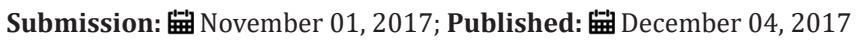

\section{Introduction}

Rasa' in any subject of life is very interesting and fundamental. Rasa as a basic quality of life begin with the soup of organic chemistry. Carbon, hydrogen, Nitrogen and oxygen along with phosphorus and sulphur consists of $96 \%$ of molecules of life in modern chemistry where as rest of minerals and elements are only traces or insignificant to its counterpart of understanding 64 arts of life in combination of emotional Rasa or Bhava, (nava rasa-09) and 63 Vikalpa of Rasa Bheda from 06 rasa etc. (shad anga pradhana shareere shad eva rasaa)

Panka' is the similar soup of all essence and essentials of life literally known as soup of mud for the growth of lotus kind of plant life. Symbolically the beauty of life as lotus is significant for its sustenance of life as water in life or life in water (our bodies compose more than $80 \%$ of water). In response to its sensitivity to the Sun lord in one variety of life to the Moon in another variety of water life. (Utpala, kamala, padma ityadi).

Together 'Rasa panka' makes perfect combination and sense of life for its symbolic expression in its quality of life. Suppose if life of Lotus like plant activity is Vata energy in its predominance is thus modulated by Sun of pitta and Moon of kapha in metaphor of the context. Understanding thus the soup of life from its beginning or origin of life, is fundamental to the basics of life from any perspective, conventional to the non conventional sense of integration in life.

Thus Rasa as a quality represent from psycho-somatic component of life from Nava rasa (09) to Shad rasa (06) in reference. Since Dravya as a basis stands for its division of 09 kaarana dravya to infinite of karya dravyas. In the somatic or dhatu component of life thus began from qualitative or guna from origin as psycho represent to micro cosmic elements or sensory world and soma to pancha maha bhutas in the context of karana dravya to karya dravya living shareera in total of 25 elemental composition as quality of life (purusha) to understand in Ayurveda. In any case Rasa is the basis of assessment in as a quality of life to decide whether from dhatu point of view, Rasa or Bhava point of view as Nava rasa for respective changes in life. Since it is now only much related to the changes of life in its living somatic perspective and based on the substances effecting life is the origin of its explanation in the context of text to start with.

Fundamental changes in dravya guna shastra vijnana refers to elaborative to concise in its frame work and hence used both as shastra (Samanya) where applicable to narrate the theory to vijnana or vishesha where it is symbolically explained in this book of reference. First substance to modulate life begin with the theory of nutrition and or Ahara dravya as samanya and vishesha to narrate and describe as necessary for the quality of life to unfold and bring changes in it accordingly the therapeutic or healing substances in vishesha should follow by in sequence.

Scholars of Ayurveda should they be benefited by the thought for the food process or food for sustenance is the key for modulation. Since food in matra kala desha avastha vishesha should act like medicine to modulate as food medicine in the context of beginning the science of dravya guna shastra vijnana in the soup of life ie Rasa panka.

\section{The concept of food as medicine in ayurveda}

Food is the cause and source for life and beyond as explained in Bhagavad-Gita the Holy Scripture or sayings, in great epic known as Mahabharata from Indian origin. Right food thus, not only enables us to heal ourselves through body-senses-mind-spirit combination of life, but also to act beyond in to our celestial form of living, according to mythology from above reference.

Food accordingly can be Satwik' or pure essence for life to sustain energies in positive response and to modulate each and every living cell with its conscious (Mind-Spirit) modulations effecting on to our gene pool functions. Second type of food sources can be Rajasik' or temperament to activate living body in response to (Sensory-Mind) modulations in to our lives. Third type is known as Tamasik' where grosser bodily functions or (Somatic) tissues sustain their energies and go for build up reactions taking place in our body.

Conscious modulations thus constantly occurring through our gene sequences (Satwa) is to boost our immune modulation to 
prevent any dysfunctions from mind/body to body/mind dualism in our lives. Tissue building reactions or bulk generating qualities of food is to bring stability in growth and development (Tamas). In between can be the (Rajas) to link both as catalyst kind of reactions to fire or fuel the boost from gross changes to subtle and subtle to gross in our physiology in response to above division of foods as explained in mythological references.

Ayurveda thus evolved from the qualitative division of Satwa, Rajas \& Tamas as the core qualities in our lives and beyond from inorganic (life less form) to organic synthesis or in to life form. In such case one can build up an argument like what we understand the food for living cells and tissues to modulate is also applicable to life beyond in celestial form depending on above quality (Satwa) for such conscious living. The evidence for such theory from mythological scriptures is today, we see so many instances of people living on breathing without drinking and eating. How our body with the pure essence of cosmic fuel? Is capable of maintaining even grosser form of our body not only to sustain the energies of life, but also keeping it healthy and free from suffering.

Some of examples for our lives can be correlated from above qualities, as explained in Ayurveda, thinking positive, coping with any amount of stress, being happy and content, high tolerance to mental and physical endeavours, like not getting emotionally upset, angry, depression and or any mental negativities is all because of 'Satwa' core energy of our life from the essence of like hood food sources is possible. Similarly getting a good night sleep or rest, not suffering from insomnia, ground level of physique and muscle strength in our body, bulk tissues, easy elimination etc is all from 'Tamas' quality and of its nature of substances through food in to us. Integrative quality, in for both above is 'Rajas' quality, like emotional well being to balanced state of desirous living. Taste of life to eat and enjoy. Food for thought or we are what we eat kind of boost in our bodily functions integrating both the grosser bodily tissues, with the sensory mind/spirit level, for our balanced living, with all three qualities or qualitative food substances is all possible to explain.

To understand more of these core qualities, Satwa is like white, shiny, light, illuminate, energetic, glow, lustre, heat and radiance etc. in physicality to physiology from the source of Sunlight modulations on earth planet from inorganic to organic or into life form is understood in Ayurveda. Similarly that Satwa, energy in our body come with the power of Digestion, balance of digestive fire, colour and complexion, vision, immune modulations, and more in to our mind with the intelligence, high tolerance, forbearance and or activation in to our life through the mind, speech and bodily regulated functions, from the source of balanced food or nutrition in our body. The activating or initiative, primary and or essential food quality into our body comes from the example of dairy sources can be organic whole cow's milk been processed.

While Tamas quality of food substances stabilise the patterns of tissue growth in to development and the strength from the bulk formation of tissues, rest patterns of sleep and restart functions improve allowing much time to heal and rejuvenate. The moon influences over plant kingdom to synthesise immune modulated defence mechanism, active principles like alkaloids to steroid kind of synthesis, from in to our body to help sustain the balance of tissues. Example for such source quality among dairy substances would be processed buffalo milk and any such bye products of dairy like cheese to yoghurt etc.

Rajas food substances activate and regulate both together in above conjunction to catalyst type of reactions in food metabolism, come from spice group, fire or heat reactions in our body and energy exchanges etc. improvisation of food maps from the post natal age group of 3-7 years of life to fix by the taste and combinations of food with the initiation of Rajas quality from in the food in to our body. Rajas doe's that regulative process of division of cells to co ordinate system functions. Seasonal variations influencing on natural sources of food substances, climate or atmosphere externally can boost in these natural substances attain Rajas quality from food in to our body. Such an example from the source of dairy substances can be the butter, butter milk and ghee processing etc.

Thus, activation or initiative process of qualities come from Satwik' food sources, sustentation come from Tamasik' food quality where as regulation comes from Rajasik' food qualities in to our lives.

Further food substances in Ayurveda find three more sub divisions based on the exclusive nature of food substances be the kind of wholesome foods for all ages to all health and its related conditions of body. The holistic food substances, by virtue of their qualities enhance the process of absorption to assimilation of nutrients in to our body. They can be used in ill health to heal and recuperate from illnesses and can also be used to promote health under rejuvenating food substances.

The second variety are selective group of individualised food substances been tailored to individual constitutional variations of seven types of our bodies, to conditions of health and ill health in consideration to compatibility of food substances, to any processing required to neutralise 18 kinds of incompatibility in food identity. They are based on our three energies known under humours of our body to care and regulate, in imbalance to find balance among.

Third variety of food substances are naturally antagonistic food substances find inadequacy in quality of food to nurture our bodies, rage imbalances in our bodily humours when not properly ingested, can also become the cause for imbalances of energies, to dysfunctions in tissue growth and development to bring allergies or intolerances towards another kind of food substances. They are un- wholesome food substances by nature tend to produce problems in our health. More interventions are needed to counter the imbalances from these food substances.

Though all three above primary qualities known as 'Satwa, Rajas and Tamas' are present in all food or natural sources, can only be understood for their predominance in a given substance. Once we know the rules and regulations of food intake to 
conscious eating always enhance and promise better nutrition by understanding the above variations naturally occurring in any kind of food supplements or natural source of food material according to Ayurveda.

Source of food from outside of our body, with its qualities varying like above, depends on taste perception in an individual is the prime modulation through the smell, colour, consistency of food to the likes and dislikes of an individual, based on food maps developed as mentioned above. Qualities from the natural sources of food material to qualities been enhanced by the skills or processing, preserving, combinations and taste synthesis is the key for further modulations taking place through our digestive fire. For example similar ingredients used by two different chefs in the preparation of food can change or variant by taste synthesis. 